\title{
The Interface of Politics and Religion in Zimbabwe: Rethinking Religious Leaders as Agents of Consecration and Repudiation
}

\section{Bekithemba Dube \\ Milton Nkoane}

\begin{abstract}
This article seeks to problematise religious figures and politicians who use religious discourses, narratives and functions to justify oppressive hegemonic systems and structures. In doing so, we show how various religious figures have amalgamated or joined together with oppressive political figures to maintain the status quo, paving the way for what we term the 'consecration' and 'enthronement' of political figures. Furthermore, we show how religious figures who failed the ZANU PF's political part of their ideology, were dislodged from enthronement due to their different understanding of democracy. To problematise oppressive religious discourses used in the politics of an oppressive status quo, we position our article within critical emancipatory research (CER) discourse, by paying attention to its tenets, such as social justice, elimination of false consciousness, and emancipation. The article references our observations and findings, deriving from document analysis, on how religious leaders have related to the ZANU PF over the years. The argument is that religion, in the context of politics, should be aimed at improving human conditions, promoting social justice and achieving emancipation, and challenging oppressive political structures. It should unmask violence and represent all religious followers fairly and equally, regardless of political affiliation.
\end{abstract}

Keywords: Consecration, repudiation, education, prophetic movements, critical emancipatory research 


\begin{abstract}
What Africans must be vigilant against is the trap of ending up normalising and universalising coloniality [dominance] as a natural state of the world. It must be unmasked, resisted and destroyed because it produced a world order that can only be sustained through a combination of violence, deceit, hypocrisy and lies (Ndlovu-Gatsheni 2013:10).
\end{abstract}

\title{
Introduction
}

It could be argued that, in Africa, religion is becoming a social problem, rather than presenting a solution for impediments people face in society. The problem emanates from the fragility and liquidity of religious narratives and discourses, which can be used to justify both good acts and oppressive structures and, as suggested by Paullkechukwu and Clara (2015:193), the problem arises from the level of conceptualisation. Many postcolonial states, including Zimbabwe, are flooded with religious groups who promise solutions for human problems and, in the process, produce more problems than solutions. In addition, the religious 'crisis is mainly manifesting itself at the ideological, theoretical and epistemological levels' (Ndlovu-Gatsheni 2015:21). Hence, using religion as a counter-hegemony strategy is informed by the United Nations Educational Scientific and Cultural Organization (UNESCO 2011:17), which states that some aspects of religious systems and knowledge impinge on national and global mindsets, and the development of critical and democratic citizens. Thus, the position of the article is that the religious narrative, in this case, the Bible, must be 'read from the perspective of the poor and marginalized, to allow social transformation' (West 1995:454). To expand in detail on the problem presented by religion, especially in the political space, we focus on two concepts, namely, consecration and repudiation.

\section{Contextualising Religion in a Political Conundrum}

Religion, in the Zimbabwean political milieu, has developed broadly in terms of consecration and repudiation. Consecration refers to religious leaders being sympathetic to a political party or the government of the day, which, in this case, is Zimbabwe's ZANU PF government, and being rewarded, by being 
enthroned, promoted and supported in their religious activities. Though Mugabe's reign as the president of Zimbabwe and the leader of ZANU PF may have come to an end, some religious groups become harbingers (forerunners) of the continued reign of ZANU PF in the political space (Gunda 2012:32). In shedding light on this, we focus on the Mapostori movements under the leadership of Reverend Ndanga, and new prophetic movements, such as Magaya and Makandiwa. In this article, repudiation refers to the treatment of political figures who dislodge dissenting religious voices that champion social justice, accountability and proper governance and the voices of people who fail political tests as interpreted from the lens of ZANU PF. As will be shown in this article, repudiation processes are costly and have reminded dissenting religious leaders that embarking on the prophetic vocation of castigating politicians has dire consequences. In elaborating on repudiation of the prophetic vocation in Zimbabwe, we will refer to Pius Ncube, Nolbert Kunonga and Walter Magaya.

\section{Theoretical Framework: Critical Emancipatory Research}

We locate this article in critical emancipatory research (CER), because it is vigilant and sensitive to the dangers posed by inequity and social injustice, and the absence of freedom, peace and hope (Mahlomaholo \& Netshandama 2010:10). Furthermore, CER catechesis the religious and social conditions of crisis, advocates for the transformation of prevailing tyrannical social structures, and displaces them with emancipatory ones (Sinnerbrink 2012:370). This approach has its roots in the critical theory of the Frankfurt School of Germany, which originated around 1923. The Frankfurt School seeks to discover 'how to make sense of the world, and of our consciousness of the world and our being-in-the-world, and of our capacity for subjectivity and agency, set against a background of enormous political forces and structures' (Farrands \& Worth 2005:49). The framework 'emerged not only out of suspicions in the academy but also out of wider social movements and struggles against oppression' (Carrette \& Keller 1999:22-23). It also emerged as a quest to move 'toward the possibilities of democratic politics and the simultaneously theoretical and emancipatory task of revealing the distortions of contemporary politics' (Anderson 2011:35).

CER has various principles that distinguish it in various fields of research oriented to emancipation and improvement of the human condition 
through dealing with challenges of religious and political arrangements of supremacy that cause dehumanisation. We focus on three principles of CER to challenge the use of consecration and repudiation of citizens through the misuse of religion and its pedagogical space. These principles are social justice, emancipation and elimination of false consciousness. We emphasise these three principles, because they are love-based, rights-based and, as Honneth (1995:129) suggests, they seek to improve human conditions. Through these principles, religion is positioned to benefit society, as opposed to being viewed as an 'impediment to economic advancement, and irrelevant for modern societies' (Lunn 2009:939), and used for subjugation in the political arena.

\section{Social Justice and the Politics of Consecration and Repudiation}

Unpacking the principle of social justice 'is an erudite response nurtured by progressive human and faith development, which supports inherent human dignity, through hybridity of different actors in [a] quest to establish a just society' (Brady 2010:8). It is an element used to recover the privileges of those placated (Traitler 2015:88) through oppressive religious and political narratives, to return to participation in democratic processes, such as freedom of speech and expressing displeasure about government systems. To achieve this recovery, social justice frequently challenges 'inequities at their source and requires people to question social and power relations' (Hankivksy 2014:11). Hence, social justice is a learned response that is fostered by progressive religious and political players. This is done in a quest for inherent human dignity through a collaborative effort (Brady 2010:8).

\section{Emancipation in the Religious and Political Landscape}

The second principle of CER is emancipation. Abel and Sementelli (2002:253) note that emancipation 'challenges oppressive hegemony, where there is an exercise of power at a decipherable cost to others'. The emancipatory interest of 'critical pedagogies focus on the scrutiny of oppressive structures; practices and systems' (Biesta 2010:10). Alvesson (1992:432) argues that emancipation describes the procedure,

through which individuals and groups become freed from suppressive 
social and ideological situations, particularly those that place socially unnecessary precincts upon development and enunciation of human consciousness.

We emphasise the role of emancipation in repudiating religious grandiloquence and political gimmicks 'that limit freedom, once these barriers have been dissolved, people can control the direction of their own lives' (Ryan 1998:260). In addition, emancipation 'awakens consciousness and brings awareness of social injustices, motivates self-empowerment and social transformation' (Stinson 2009:506).

\section{Elimination of False Consciousness in a Mind Liberation Struggle}

Elimination of false consciousness stems from a Foucauldian notion of power dynamics and the Freirean concept of critical pedagogy (McKern 2013:425). It is a principle that aims to 'solve practical problems by critical thinking and the use of knowledge which is free from superstition and prejudice' (Steinvorth 2008:400). This principle is necessary for this article, because 'it looks at, exposes, and questions hegemony, traditional power assumptions held about relationships, groups, communities, societies, and organisations to promote social change' (Given 2008:140). We concur with Freire (1990:33), that eliminating false consciousness 'enables people to amend issues of power imbalance, which may contribute to the end of religious and political oppression'. Oppression through politics and religion has led many people to accept oppressive conditions as normal. As such, revolutionary efforts that seek social transformation are rejected in favour of peace-making rhetoric, which seldom challenges oppression. Some politicians strive to create false consciousness and, consequently, religion is used to lower people's expectations of earthly satisfaction, instead, they anticipate a better future in heaven (Mtata 2013:27). Some politicians and religious leaders enjoy the reciprocal relationship of consecration. Freire (2000:144) brings this home by stating that,

oppressed people become so powerless that they do not even talk about their oppression. If they reach this stage of oppression, it creates a culture wherein it is forbidden to even mention the injustices that are 
being committed. The oppressed are silenced. They have no voice and no will.

To oppressive politicians, this thinking (oppressing people) enforces a certain level of social cohesion for the maintenance of public order (Bangura 1994:1). Hence, Marx saw religion as a drug meant to delude the masses, so that they could not raise concerns against the ruling classes, which negates efforts to achieve full democracy, social justice and emancipation in Zimbabwe. Religious teaching that is tailor-made to oppress people worsens this situation. The principle of elimination of false consciousness is crucial in this article, in the sense that Zimbabwe is under political and religious siege, and people are being encouraged to be resilient in the face of difficulties, and those who fail the political test of regime obedience are subjected to repudiation.

\section{Situating Democracy in Religion and Political Discourse in Zimbabwe}

The relationship between religion and politics has never been 'conventional rather, the rapport is intricate because of the convolutions inherent in the politicization of religion' (Oshewolo \& Maren 2015:1). It is characterised by ambiguity and ambivalence. We analyse the use of religion in politics (especially when it relates to social injustice) because religion and politics have 'direct bearing on the political and socio-economic well-being of the people' (Manyeruke \& Hamauswa 2013:283), especially when religion is exercised within the context of oppression. Religion in the context of the politics of ZANU PF has redefined democracy to be understood as supporting ZANU PF enthronement. Any other interpretation fails the political test, and is punishable. In essence, democracy is defined as support for Robert Mugabe (former president of Zimbabwe) and, more recently, his wife, Grace Mugabe, who is gaining momentum in the political landscape. Those who have a different view of democracy are treated as promoting a regime change sponsored by Global North forces, even in the absence of ties with Global North agents, as in the case of Pastor Evan Mawarire (Al Jazeera 2016). The implication is that religious leaders who intend to enjoy this form of democracy must be ZANU PF members who visibly support Robert and Grace Mugabe, or face the risk of being dislodged or repudiated. In a quest to remain relevant 
in the context of ZANU PF, religious leaders such as Emmanuel Makandiwa promoted an anti-sanctions campaign (Sundaynews 2017:1; Chitando \& Gunda 2013:21).

\section{Conundrum of Consecration in Political and Religious Auspices \\ Johannes Ndanga and the Apostolic Christian Church: Politics of Consecration}

The politics of consecration is dominant in the interface of religion and politics. We refer to the religious organisation called the Apostolic Christian Council of Zimbabwe (ACCZ), commonly known as Mapostori, under the leadership of Johannnes Ndanga, who claims to present the interests of indigenous religious churches in Zimbabwe. This religious organisation has declared, as reported by Dembedza (2013:4), that 'Apostolic faith churches will continue to support President Mugabe and Zanu-PF to ensure that the party resoundingly wins the 2018 harmonised elections'. The Mapostori movement is one of the biggest religious movements in Zimbabwe, making it one of the richest hunting grounds for politicians. In most cases, Mapositori church leaders have openly pledged the support of their members to ZANU PF (Manyeruke \& Hamauswa, 2013:295), making religion an issue in the electoral process (Familusi 2013:24). ZANU PF apologists never criticise ZANU PF, despite the party's obvious, gross human-rights abuses (Machoko 2013:12). Church leaders are co-opted as 'politically reliable' activists; consequently, accepting Mugabe and ZANU PF's superiority (Machoko 2013:13). In an attempt to enthrone Mugabe and his wife, some religious leaders even make themselves guilty of heresy. For instance, leaders of the Epworth, Mudzi North and Rushinga branches of Vadzidzi vaJesu, which is a branch of the Apostolic Christian Church, testified that the church eulogised Mugabe's leadership at a church service and urged congregants to support him because 'he carries the blood of Jesus' (Ndlovu 2011:2). In light of the foregoing argument, Bourdillon (1984:54) notes that politicians will always be ready to use such powerful tools as religious symbols to further their own interests. The symbols may then begin to acquire new connotations for people, connotations that might dilute the symbols of their sacred quality and rob them of their poetic power. This creates a false consciousness among religious followers, which, through the lens of CER must 
be challenged and negated through all possible counter-hegemony strategies.

Because of the pledge to support ZANU PF and its programmes, Ndanga has been exonerated in scandalous issues associated with his name. For example:

[S]ome churches, among them Mugodhi Apostolic Church, Vimbiso ya Jehovha Apostolic Church, Zion Christian Church (ZCC) and Bethsaida Apostolic Church had sent representatives to try to recover about US\$400 000 which was lost through the botched housing scheme but to no avail (Zimbabwe Online News 2015:4).

Therefore, failure to prosecute on political and religious grounds is tantamount to social injustice, which the framing of the article calls for unmasking and eradication, to produce a religious and political interface anchored on social justice. Thus, we conclude this section by arguing that political consecration provides opportunities for religion to be exploited in power struggles over religion, class, race, and gender, and all the boundaries that are continually being revived by those in power, or those seeking power (Dreyer 2007).

\section{Godfrey Nzira and Consecration}

To bring closer the aspect of reciprocal enthronement or consecration in a political area, we draw readers' attention to Godfrey Nzira, the leader of John Marange Apostolic Church; under this religious banner, Robert Mugabe was the consecrated bishop The organisation's leadership asked Mugabe to allow them to spearhead ZANU PF's election campaigns for future national elections (Eagle 2010:13). Musendekwa (2011:50) reports that another apostolic followers under Madzibaba Godfrey Nzira had been pardoned by the president for his (follower) sexual abuses on 'religious members coerced members of the apostolic sect and other churches in Muzarabani to rally behind ZANU PF ahead of possible elections in 2008'. To this end, we argue that religion is used for personal gain at the expense of suffering citizens. In this regard, we agree with Enroth (1992:41), that religious leaders are holders of spiritual power and, unfortunately, such power is often abused, or used to propagate evil in society Such abusive acts should be unmasked and rejected if Zimbabwe intends to enjoy the true fruits of independence and democracy, not the fruits as interpreted by ZANU PF. 
Another incident of reciprocal enthronement quoted by Musendekwa (2011:55) involves a visit by President Mugabe to the Zion Christian Church (ZCC) shrine, where he officially opened an 18 000-seat conference hall at Mbungo Estate. In return, Nehemiah Mutendi, the leader of ZCC, 'praised the president, assured support from his huge following, and declared President Mugabe a leader sent from God, despite his acts [injustices] that contradict the teaching of the God that sent him' (Gunda 2012:33). This declaration creates a false consciousness, because religious followers often believe that everything prophets say is true.

Paul Mwazha is another religious figure who told his African Apostolic Church devotees to chant ZANU PF political slogans, and who signed a ZANU PF anti-sanctions petition relating to travel restrictions imposed on Mugabe and top ZANU PF officials (Nkala 2011). Mugabe reciprocated by giving Mwazha the Order of Merit Award for his outstanding service to the development of Christianity in Zimbabwe and establishing and sustaining a five-star indigenous church (Sunday Mail Reporter 2012). In this case, religion creates a sectarian tendency that causes some religious figures to do anything in the name of religion to ensure that their adherents gain positions or offices (Afolabi 2015:49). Some church leaders have been seen to revert to corruption and a search for material goods, and, above all, ethnicity and favouritism has entered these institutions (Gumo, Akuloba \& Omare 2012:34). In this case, religious followers are not emancipated to participate in the democratic process by identifying politicians who suit their needs and change their conditions, instead, they experience prejudice, fear, victimisation and violence.

\section{Obadiah Musindo and the Politics of Reciprocity}

Another noticeable example in relation to the politics of consecration relates to Reverend Obadiah Musindo. He runs an organisation called Destiny of Africa Network Housing Development. In a quest for consecration, according to Guma (2013:4), Musindo described Mugabe as a 'Black Moses' and promised that he would recruit more than 2 million votes for ZANU PF, which he did by doling out residential stands and creating employment. A Bulawayo24 Staff Reporter (2013:4) reported that Musindo had joined a growing list of 'men of God' who had close links to ZANU PF, and who have been caught on the wrong side of religion. To reciprocate Musindo's efforts, ZANU PF exonerated 
him from accusations of abuse that were levelled against him. Through this political arrangement, religion becomes an ideological tool for the dominant classes to sanction and moralise social evil, and for exploitation of the oppressed classes (Okoro 2012:251). In such cases, religious leaders become ruling party activists who may practice oppression in anticipation of favours. In this regard, a prophetic mandate is shown by Old Testament prophets, such as Elijah and Jeremiah, who condemned and disapproved of oppressive hegemony, injustice and violence.

\section{Repudiation Process in the Context of Politics}

While the reciprocal relationships involved in the politics of consecration are evident at the interface of politics and religion in Zimbabwe, the politics of repudiation is a tool for quashing dissenting voices representing democracy. The politics of repudiation is the result of efforts by politicians and religious leaders (Church and Civil Society Forum 2012:18) to cement oppressive hegemonic forces. According to Mutangi (2008:545), 'political harassment [repudiation] of religious leaders is one of the problematic areas that need to be addressed as soon as possible before it gets out of hand'. A counterhegemony strategy has, since the independence of Zimbabwe in 1980, been inevitable, as observed by Ndlovu-Gatsheni (2009:22). Zimbabwe has been 'antagonising under a nationalist regime whose political essence survives through violent means against recalcitrant expressions' and, more recently, through religious organisations such as some Apostolic churches. This can be achieved by finding better ways of theorising and critiquing religion, and taking the religious struggles for liberation from hegemonic forces forward in contemporary religious conjecture (Ndlovu-Gatsheni 2015:23).

In this section, we focus on religious leaders and organisations that have experienced enthronement by ZANU PF, and which were later repudiated for failing political tests, as interpreted from the perspective of Zimbabwean political narratives. We allude, furthermore, to the way the narratives of the Global North have found entry into political and religious discourse as an excuse for religious competency and accountability, which are paramount for progressive and democratic societies. In doing so, we focus on religious movements and prophets, such as Walter Magaya, Nolbert Kunonga, Pius Ncube and Evan Mawire. It is through a snap view of these people and organisations that Sanchez's (2006:25) observation, that politics is a game of 
power, is valid, especially when it (politics) has a religious backing. This power, not perceived in a Foucauldian (1992) sense of emancipation, but for social control, perpetrates social injustices and eliminates perceived enemies. Religious leaders are repudiated because they are opposed to narratives that hold the masses in check (Paulkechukwu \& Clara 2015:193). In addition, such prophets are arguably against 'skewed nationalism that is not progressive; a nationalism that is pandering to primordial pathologies, leaving it open to easy derision' (Ndlovu-Gatsheni 2009:358), which produces religious leaders and politicians who are unaccountable and untouchable. According to Gunda (2012:39), the African public sphere is heavily 'biblified', and this 'biblification' has only helped the elite to avoid accountability by hiding behind religiosity. To ZANU PF, religion and its leaders must be kept under lock and key, and be encouraged to control and influence the general populace.

\section{The Repudiation of Pius Ncube}

Pius Ncube, a Catholic priest, rose to prominence in the political milieu when he castigated the Mugabe government for gross injustices, such as the Gukurahundi massacre in Matabeleland (Chitando, \& Gunda 2013:171) and operation Murambasvina in 2005. He became famous when he prayed that Mugabe would die, so that violations of human rights could cease in Zimbabwe. Before his repudiation, Pius Ncube, in a bold statement, as cited by Unruh (2004), said:

I am not going to be quiet when my people are suffering, I have a right to talk. That is why I was called to this office - to talk on behalf of the suffering.

Ncube also became undesired by the regime due to his international connections with the Global North, which is, according to the ZANU PF narratives, a champion of regime change in Zimbabwe; hence, there was a need and justification to dispose of Ncube (Church and Civil Society 2012:18). Since Ncube is Catholic, he was found to have contravened the Catholic law of celibacy by engaging in sexual activities with a woman, Rosemary Sibanda. The sexual escapade, whether true or not, reduced the prophetic voice of Ncube, and lead to his repudiation. However, the sexual accusation remains a 
controversial issue, given that the state was one of the forerunners in wanting to find him guilty.

When we compare the experience of Ncube with that of Madzibaba Nzira, we see how politicians handle cases relating to people perceived to be friends and enemies of the state. Nzira was pardoned despite being found guilty by a court of law of raping congregants, which, on its own, was dehumanising for the victims. For his part, Ncube was involved in consensual sexual activities with Sibanda (no police report was made), yet, he was made a public figure of ridicule and shamed, because he spoke out against injustices perpetrated by the state. In the case of Pius Ncube, we see reciprocal repudiation. That is, if one speaks of the evil of that state, one must also be prepared for your own 'evils' to be exposed, whether true or fabricated. Therefore, unlike the Mapostori, Ncube succumbed to the politics of reciprocal repudiation and, since then, his involvement in issues of social justice has been tainted. He has withdrawn from the public eye and avoids the castigation of ZANU PF. The story of Pius Ncube reminds us that, often, politicians 'caricature and trivialise the religious beliefs and practices of citizens, especially if they happen to be from a religious, racial, or ethnic community different from their own' (Garelle 2002:52). In light of this, Gatsheni-Ndlovu (2015:23) is right in noting that there is a need for better ways to theorise religion, of critiquing and taking religious struggles for the liberation from hegemonic forces forward in contemporary religious conjecture, with the aim of eliminating all religion-oriented abuses aimed at self-justification and political consecration and repudiation.

\section{The Enthronement and Repudiation of Nolbert Kunonga}

Gilbert Kunonga, of the Anglican diocese of Harare - a breakaway group from the Church of Province of Central Africa under the leadership of Chad Gandiya - experienced both sides of the coin (enthronement and repudiation), confirming the claim that, in politics, there are no permanent friends or enemies. When the dancing no longer responds to the tune of the song, there is a likelihood of repudiation in politics. The Anglican Church in Zimbabwe has been divided since a breakaway bishop, Kunonga, was excommunicated in 2007 for inciting violence in sermons supporting Mugabe's party (Church and Civil Society Forum 2012:22). In February 2008, Bishop Kunonga barricaded himself inside the Cathedral with members of the ZANU PF youth militia after calling church members 'marked dissidents and traitors' (UNHCR 2010:2). 
During this period, Kunonga enjoyed the enthronement awarded by ZANU PF youths and, and the ownership of the property of the Anglican Church in Harare. Consequently, Anglican members aligned with Chad Gandiya were denied access to the premises, to which they had directly or indirectly contributed to developing. From the unfolding of these events, it is clear that, when politics enters the religious world, the people aligned to the present government are likely to benefit more than those who publicly declare war or oppose the present government. While supporting the government is admirable, it should be done in such a way that it promotes social justice, emancipation and social transformation. We argue this in support of Bakare, cited by Tooley (2016:1), about the conduct of police aligned to Kunonga:

The police officers do not only prevent but beat, harass and arrest us, having declared our church premises no-go areas.

The involvement of police in support of Kunonga affected the worship life of the Anglicans in Zimbabwe. However, the courts later declared Kunonga to be an illegitimate leader of the Anglicans and, in the process, he lost Anglican property of which, earlier, the court had declared that he was the rightful owner (The Zimbabwean 2012). Kunonga's fall from grace and repudiation occurred after President Mugabe questioned the significance of Kunonga's role in amalgamating ZANU PF. In Mugabe's words, Kunonga has 'too many enemies and is unnecessarily discrediting the party' (Nehanda Radio 2012:2). The ruling party had no choice but to withdraw its support of Kunonga, since he had failed the political test for his consecration; hence, the inevitable repudiation.

\section{Ambivalence in Walter Magaya's Consecration and Repudiation}

Walter Magaya is a prominent prophet who influenced the prophetic movement in Zimbabwe. We bring Magaya into this picture because of his perceived support of the ruling party. He has financial muscle, though the source of his funds is unclear. He owns one of the biggest hotels in Zimbabwe and recently commissioned 46000 stands for housing projects. This is applauded in the sense that the housing project will improve living conditions of religious supporters (Nyoni 2016:2). However, the critical question is, how 
can an individual acquire 46000 stands, while the average Zimbabwean finds it hard to acquire one stand? What does the distribution of land among the people of Zimbabwe entail? How can one justify democracy and social justice when one has the capacity to own all these stands, while an average Zimbabwean cannot afford one? Could this also be one of the ways that politicians have seen to use Magaya and his followers for enthronement? Is the appearance of politicians in Magaya's hotel and housing projects a mere coincidence, or a political strategy for enthronement? The answers to these questions are critical for situating Magaya in the political arena of Zimbabwe, and in issues of social justice.

In the case of politics and repudiation, soon after commissioning his housing project, the prophet was summoned by the police to answer rape allegations (ZWNews 2016). At the time of writing this article, several women were presenting evidence of rape, sexual harassment, murder and corruption. It will be interesting to note how Magaya's case will unfold. Could it be time for repudiation after enthronement?

\section{Conclusion}

This article interrogated the interface of religion and politics in Zimbabwe. It emerged from the article that there are two main trends in the interface, namely, consecration and repudiation, as means to maintain the status quo as well as advance political endeavours. While religious leaders have the democratic right to be involved in the political arena, the argument of this article, informed by CER, is that involvement by religious leaders should be premised on emancipation, social justice and taking the side of the oppressed. It is in this milieu that religion 'reclaims its paramount space in social transformation and religious discourses devoid of superstition and prejudice' (Steinvorth 2008:400). Therefore, to achieve this reclamation, the article advocates for the unmasking and challenging of all religious narratives and subjects that champion individual political appetites at the expense of the suffering masses of Zimbabwe, whose rights to democracy are premised in ZANU PF and religion-informed harbingers. This goal can be achieved, as suggested by Beyers (2015:1), if we once again place on the table for debate the relation between politics and religion; so that religion can engage in social issues positively, and find new ways of expressing neighbourly love and improving the lives of all. 


\section{References}

Abel, C.F. \& A. Sementelli 2002. Power, Emancipation and the Administrative State. Administrative Theory and Praxis 24,2: 253 - 278.

https://doi.org/10.1080/10841806.2002.11029361

Afolabi, O.O. 2015. The Role of Religion in Nigerian Politics and its

Sustainability for Political Development. Nova Journal of Sufism and Spirituality 3/2: 42 - 49.

Al Jazeera 2016. Mugabe: Evan Mawaire Sponsored by Foreign Countries. Zimbabwean President Accuses Pastor who Led Protests of Being Backed by Countries Set on Destabilising the Government. Al Jazeera. News. Politics. Available at https://www.aljazeera.com/news/2016/07/mugabeevan-mawarire-sponsored-foreign-countries-160719133307531.html

(Accessed 2 July 2017.)

Alvesson, M. 1992. On the Idea of Emancipation, Management and

Organization Studies. The Academy of Management Review 17,3: 432454. https://doi.org/10.5465/amr.1992.4281977

https://doi.org/10.2307/258718

Anderson, J. 2011. Situating Axel Honneth in the Frankfurt School Tradition.

In Petherbridge D. (ed.): Axel Honneth: Critical Essays. Boston \& Leiden:

Brill. https://doi.org/10.1163/ej.9789004208858.i-439.13

Beyers, J. 2014. The Church and the Secular: The Effect of the Post-secular on

Christianity. HTS Teologiese Studies/ Theological Studies 70,1: 1 - 12.

https://doi.org/10.4102/hts.v70i1.2605

Bangura, Y. 1994. The Search for Identity: Ethnicity, Religion and Political

Violence. Occasional Paper 6. World Summit for School Development 1

December. Geneva: United Nations Research Institute for Social Development.

Biesta, G. 2010. A New Logic of Emancipation. The Methodology of Jacques Ranciere. Educational Theory 60,1: 39 - 58.

https://doi.org/10.1111/j.1741-5446.2009.00345.x

Bourdillon, M.F.C. 1984. Religious Symbols and Political Change. Zambezia 5,XIL: 39 - 54.

Brady, J.A.O.P. 2010. A Burning Desire for Social Justice. Religious

Education 105,1:8 - 11. https://doi.org/10.1080/00344080903472634

Bulawayo24 Staff Reporter 2013. Mugabe Priest in Vulgar Video Storm.

Bulawayo24 News 28 April 2013, at 10:34. Available at: 
http://new.bulawayo24.com/index-id-News-sc-National-byo-29569.html (Accessed 29 June 2017.)

Carrette, J. \& M. Keller 1999. Religion, Orientation and Critical Theory, Race, Gender and Sexuality at the Lambeth Conference. Theology and Sexuality 6,11: 21 - 43.

https://doi.org/10.1177/135583589900601103

Chitando, E. \& M.R. Gunda 2013. Prophets, Profits and the Bible in Zimbabwe. Festschrift for Aynos Masotsha Moyo. Bible in Africa Studies.

Volume 12. Nürnberg: University of Bamberg Press.

Chitando, E., N.T. Taringa \& T.P. Mupuranga 2014. Zimbabwean Theology and Religious Studies during the Crisis Years 2000-2008. Preliminary Study. Studia Historiciae Ecclesiasticae 40,1: 173 - 189.

Church and Civil Society Forum 2012. Development of a Church and Civil Society Forum: Conflict Early Warning Mechanism. July. Harare: Church and Civil Society Forum.

Dembedza, P. 2013. Apostolic Church Pledge Allegiance to President. The Herald 29 October 2013. Available at:

https://www.herald.co.zw/apostolic-churches-pledge-allegiance-topresident-zanu-pf/ (Accessed 29 June 2017.)

Dreyer, J.S. 2007. The National Policy on Religion and Education in South Africa: Reflections from a Public Practical Theology. Practical Theology in South Afica = Praktiese Teologie in Suid-Afrika 22,2: 40 - 60.

Eagle, D.F. 2010. Vapostori demand that Mushowe is Replaced. Zimbabwe Metro 11 August.

Enroth, R.M. 1992. Churches that Abuse. Grand Rapids: Zondervan.

Familusi, O.O. 2013. Religious Factors in the Electoral Process and the Quest for Enduring Democracy in Nigeria. Humanity and Social Sciences Journal 7,1: 23 - 32.

Farrands, C. \& O. Worth 2005. Critical Theory in Global Political Economy Critique? Emancipation? Critical Theory on Global Political Economy. Capital and Class 29,1: 43 - 61.

https://doi.org/10.1177/030981680508500113

Freire, P. 1990. Education for Critical Consciousness. New York: Continuum. Freire, P. 2000. Historical Conditioning and Levels of Consciousness. The Politics of Education, Culture of Silence. Macebo, D. (trans.). London: Bergi \& Garvey.

Garelle, B. 2002. Learning to Live with Difference. Teaching about Religion 
in Public Schools in Public Schools in the United State. New York: Harper.

Given, L.M. (ed.). 2008. The Sage Encyclopaedia of Quantitative Research Methods. 1 and 2. London: Sage.

https://doi.org/10.4135/9781412963909

Guma, L. 2013. Preacher who Raped Maid Five Times Now Targets Two Million Votes for Mugabe. Nehanda Radio 11 March 2013. Available at: http://nehandaradio.com/2013/03/11/preacher-who-raped-maid-5-timesnow-targets-2-million-votes-for-mugabe/ (Accessed 1 July 2017.)

Gumo, S., A. Akuloba \& S.G. Omare 2012. Religion and Politics in the Contemporary Kenya. European Scientific Journal 8,18: 29 - 41.

Gunda, M.R. 2012. Rewriting the Bible or Debiblifying the Public Sphere?

Proposal and Propositions on the Usage of the Bible by Public Figures in Zimbabwe. In Gunda, M.R. \& J. Joachim (eds.): The Bible and the Politics in Africa. Bambeng: University of Bambeng Press.

Hankivksy, O. 2014. Intersectionality 101. Vancouver, BC: Institute for Intersectionality Research \& Policy, Simon Fraser University.

Honneth, A. 1995. The Structure for Recognition. The Moral Grammar of Social Conflicts. Cambridge: The MIT Press.

Lunn, J. 2009. The Role of Religion, Spirituality and Faith in the Devil. A Critique of Theory Approach. Third Quarterly 30,5: 937 - 951.

https://doi.org/10.1080/01436590902959180

Machoko, C.G. 2013. African Initiated Churches and Party Politics: Zimbabwean Experience. The International Journal of African Catholicism 4,1: 1 - 40.

Mahlomaholo, M.G. \& V.O. Netshandama 2010. Sustainable Empowering Learning Environments: Conversations with Gramsci's Organic Intellectual. The intellectual: A Phenomenon in Multidimensional Perspectives. Oxford: Interdisciplinary Press.

Manyeruke, C. \& S. Hamauswa 2013. Prophets and Politics in Zimbabwe. In Chitando, E., M.R. Gunda \& J. Kügler (eds.): Prophets, Profits and the Bible in Zimbabwe. Bamberg: University of Bamberg Press.

McKern, J.A. 2013. The Origins of Critical Theory in Education: Fabian Socialism as Social Reconstructionism in Nineteenth Century Britain. British Journal of Educational Studies 61,4: 417 - 433. https://doi.org/10.1080/00071005.2013.824947

Mtata, K. (ed.). 2013. Religion: Help or Hindrance to Development? The 
Lutheran World Federation: Communion of Churches. Document No. 58/2013. Berlin: The Lutheran World Federation.

Musendekwa, M. 2011. Messianic Expectations as Prophetic Responses to

Crises: A Zimbabwean Perspective. Master's thesis. University of Stellenbosch, Stellenbosch.

Mutangi, T. 2008. Religion, Law and Human Rights in Zimbabwe. African Human Rights Law Journal 8: 526 - 545.

Ndlovu, R. 2011. Mugabe Push for Pulpits' Pulling Power. Mail \& Guardian

16 November 2011. Available at https://mg.co.za/article/2011-09-16mugabe-push-for-pulpits-pulling-power (Accessed 30 June 2017.)

Ndlovu-Gatsheni, S.J. 2009. The Ndebele Nation: Reflections on Hegemony, Memory and Historiography. Pretoria: UNISA.

Ndlovu-Gatsheni, S.J. 2013. Why Coloniality in the $21^{\text {st }}$ century? The Thinker for Thoughtful Leaders 48,1: 10 - 15.

Ndlovu-Gatsheni, S.J. 2015. Decoloniality in Africa. A Continuing Search for a New World Order. Australian Review of African Studies 36,2: 22 - 50.

Nehanda Radio 2012. Why Mugabe dumped Bishop Kunonga. Nehanda Radio, 6 December 2012. Available at:

http://nehandaradio.com/2012/12/06/why-mugabe-dumped-bishopkunonga/ (Accessed 30 June 2017.)

Nkala, S. 2011. Apostolic Sects Slammed. All Africa 21 May 2011. Available at: $\quad$ www.allafrica.com/stories/201105230866.html (Accessed 2 September 2016.)

Nyoni, D. 2016. Prophet Magaya Unveils 5000 housing units in Bulawayo. Nehanda Radio, 18 August 2016. Available at:

http://nehandaradio.com/2016/08/18/prophet-magaya-unveils-5-000housing-units-bulawayo/ (Accessed 2 July 2017.)

Okoro, K.N. 2012. Religion in an Oppressive Society: The Antebellum Example. Open Journal of Philosophy 2,4: 251 - 259.

https://doi.org/10.4236/ojpp.2012.24037

Oshewolo, R.M. \& B.A. Maren 2015. Religion and Politics in Nigeria. International Journal of Politics and Good Governance 6,3: 1 - 12.

Paullkechukwu, O. \& O. Clara 2015. Religion and Politics in Nigerian Society:

Problem and Prospects. (A Philosophic Probe.) Open Journal of Philosophy 5: 193 - 204. https://doi.org/10.4236/ojpp.2015.53024

Ryan, J. 1998. Critical Leadership for Education in the Post-modern World: Emancipation, Resistance and Communal Action. International Journal 
of Leadership in Education, Theory and Practice 1,3: 257 - 278. https://doi.org/10.1080/1360312980010303

Sanchez, R. 2006. Society and Political Power in Simón Rodríguez. Logoi 9: $25-51$.

Sinnerbrink, R. 2012. Critical Theory as Disclosing Critique. A Response to Kompridis. Constellations 19,3: 370 - 381.

https://doi.org/10.1111/cons.12003

Steinvorth, U. 2008. On Critical Theory. Analyse \& Kritik, Journal of Philosophy and Social Theory 30,2: 399 - 423.

https://doi.org/10.1515/auk-2008-0204

Stinson, D.W. 2009. The Proliferation of Theoretical Paradigms Quandary.

How one Novice Researcher Used Eclecticism as a Solution? The

Qualitative Research 14,3: 498 - 523.

Sunday Mail Reporter 2012. Archbishop Mwanza Conferred with Order of Merit. Sunday Mail 2 July 2012.

Sunday News 2017. Daily Divinity Question and Answers. Available at: http://www.sundaynews.co.zw/daily-divinity-questions-and-answers-19/

(Accessed 29 June 2017.)

The Zimbabwean 2012. Court Rejects Kunonga Appeal in Anglican Property

Row. The Zimbabwean 24 October 2012. Available at:

http://www.thezimbabwean.co/2012/10/court-rejects-kunonga-appeals-

in/ (Accessed 23 March 2017.)

Tooley, M.D. 2016. Mugabe's anti-Christian Persecution. Assyrian International News Agency. Harare: Longman.

Traitler, R. 2015. Mission on the Move for Justice and Peace. The Case of the

European Project for Interreligious Learning. International Review of Mission 104,1: 83 - 90.

https://doi.org/10.1111/irom.12078

United Nation Educational Scientific and Cultural Organization (UNESCO)

2011. Making Textbook Content Inclusive: A Focus on Religion, Gender and Culture. Fontenoy: UNESCO.

UNHCR 2010. Country Advice, Zimbabwe. Available at:

https://www.unhcr.org/4cd96ab29.pdf

(Accessed 1 September 2016.)

Unruh, K. 2004. Archbishop Pius Ncube of Zimbabwe: Human Rights Champion. $\mathrm{PhD}$ Thesis. Winnipeg: University of Winnipeg.

West, G. 1995. Reading the Bible and Doing Theology in the New South 
Africa. In Daniel, M. (ed). The Bible in Human Society: Essays in Honour of John Rogerson. Sheffield: Sheffield Academic Press.

ZWNews 2016. Magaya Case: Raped Woman Raises New Issues. ZWNews, 28 September 2016. Available at https://zwnews.com/magaya-case-latest/ (Accessed 24 March 2017.)

Zimbabwe Online News 2015. Knives out for Ndanga. Zimbabwe Online News 29 May 2015. Available at:

https://www.zimbabweonlinenews.com/\%EF\%BB\%BFknives-out-forndanga/ (Accessed 10 April 2018.)

Bekithemba Dube University of the Free State

Bloemfontein DubeB@ufs.ac.za

Milton Molebatsi Nkoane Educational Psychology University of Zululand nkoanem@unizulu.ac.za 